\title{
SiM
}

\section{Women as Collaborative Leaders on Rangelands in the Western United States}

\author{
By Laura Van Riper
}

\section{On the Ground}

- In recent years women have become more visible as leaders of collaborative range management in the western United States. Drawing on the experiences of four such women, gender aspects of leadership and community activism are explored.

- The four women leaders consider their efforts as "nothing special" and "business as usual"; gender considerations are not prominent in how they view their success.

- Personality traits are important determinants of exceptional leadership. Although such traits are found in both men and women, there may be cases where the more feminine attributes that emphasize peacemaking, community welfare, networking, and consensus building facilitate the management of complex problems.

- Collaborative leadership is vital for rangeland management. Recruiting and training such leaders should focus on identifying those with appropriate personality traits and aptitudes-regardless of gender-and providing them with the tools, skills, and support networks for success. The four successful women ranchers described here give us tangible models to replicate.

Keywords: collaborative rangeland management, rangeland conflict management, ranching history and gender, gender and community activism, Rural Voices for Conservation Coalition, Sustainable Northwest, Shoesole Group, Stewardship Alliance of Northeast Elko, Ranching Heritage Alliance, Yainix Partnership, Klamath Basin Restoration Agreement, Central Idaho Rangelands Network, National Riparian Service Team.

Las mujeres como líderes en colaboración en los pastizales y tierras silvestres del oeste de los Estados Unidos

\section{Perspectiva desde el campo:}

- En los últimos años las mujeres se han vuelto más visibles como líderes de gestión pastoril colaborativa en el oeste de los Estados Unidos. Se exploran los aspectos de género del liderazgo y activismo comunitario a la luz de las experiencias de cuatro de estas mujeres.

- Las cuatro mujeres líderes consideran que sus esfuerzos no son "nada especial" y que se trata de "algo de rutina". Las consideraciones de género no son importantes en la forma en que visualizan su éxito.

- Los rasgos de personalidad son factores determinantes importantes para un liderazgo excepcional. Aunque tales rasgos se encuentran tanto en hombres como en mujeres, podría haber casos en los que los atributos más femeninos que enfatizan la conciliación, el bienestar comunitario, el establecimiento de vínculos y la construcción de consensos faciliten el manejo de problemas complejos.

- El liderazgo colaborativo es vital para el manejo de los pastizales y tierras silvestres. El reclutamiento y capacitación de tales lideres debería enfocarse en identificar a quienes cuenten con los rasgos y aptitudes de personalidad adecuados -independientemente del género- $y$ en dotarles de las herramientas, habilidades y redes de apoyo para el éxito. Las cuatro mujeres granjeras descritas aquí nos proporcionan modelos tangibles dignos de ser replicados. 
T his paper is primarily a synopsis of a panel presentation given during a symposium entitled "Women as Change Agents in the World's Rangelands," held at the 66th Annual Meeting of the Society for Range Management in Oklahoma City. ${ }^{\mathrm{i}}$ My purpose is to consider the role that women, through their effort and example, are playing in shaping the changing landscape of range management in the western United States. As a symposium co-organizer, I invited four women ranchers to participate in this panel because they are widely recognized as successful leaders of land-management collaborations in Arizona, Idaho, Oregon, and Nevada.

In this paper I do several things. I begin with overviews of: 1) history concerning gender and ranching, 2) background on women as community activists and leaders, and 3) examples of women as leaders of land-management collaborations. In this latter section I present the stories of the four women panelists. I then discuss the personal motivations and qualities that have made these women unique, and speculate to what extent these may be attributable to gender or personality factors. I close with a brief assessment of where we go from here.

Specifically, the highlighted women are founding members of collaborative, community-based efforts focused on changing the manner in which ranching, rangeland issues, and conflicts are addressed. These efforts share a number of common attributes and processes, including:

- A focus on cooperation, building and advancing relationships, and communication that fosters extended dialogue as a way to engage, understand, and develop solutions that address people's differing perspectives and needs;

- A consideration of issues from a holistic perspective and a recognition that the social, economic, and ecological dimensions are interconnected pieces of the whole; and

- An attempt to redistribute power through: 1) the use of democratic processes, 2) a concern for equity and an ethic of caring, and 3) a focus on public (lay) education as well as participation in traditional science and a broad acceptance of alternative ways of knowing (i.e., subjective, relational, experiential).

The stories presented here provide local, concrete examples of the experiences and perspectives of women working in particular places. These help inform ongoing considerations of the increasingly important role that women are playing as leaders in the world of collaborative rangeland management,

\footnotetext{
View the author's introductory video (see video S1 at http://dx.doi. org/10.2111/RANGELANDS-D-13-00041.s1) as well as highlights of the four panelists: Robin Bois (see video S2 at http://dx.doi.org/10.2111/ RANGELANDS-D-13-00041.s2), Wink Crigler (video S3 at http://dx.doi. org/10.2111/RANGELANDS-D-13-00041.s3), Becky Hyde (video S4 at http://dx.doi.org/10.2111/RANGELANDS-D-13-00041.s4), and Caryl Elzinga (video S5 at http://dx.doi.org/10.2111/RANGELANDS-D13-00041.s5).
}

their approaches and motivations, and how women (and men) can be further supported in these roles. The decision to focus on the stories of women ranchers, by its nature, supports a feminist approach not only because it purposefully highlights the contributions of women, but also because it gives voice to a traditionally underrepresented perspective within the western ranching narrative.

When compared to other female activists, leaders, and problem solvers, these four women share similar characteristics, qualities, and motivations. However, the degree to which gender influences these four women remains an interestingbut unresolved - question worthy of future study. The success of these women may possibly be tied more to their feminine leadership styles and qualities than to their gender. Efforts to empower more individuals to take on similar roles could focus on identifying women and men with similar motivations, qualities, and approaches and creating opportunities for them to self-select as leaders, gain the necessary social and technical skills, and then link to diverse support networks.

\section{Gender and Ranching in the American West}

Prior to the 1970s, the traditional narrative of western settlement and ranching tended to characterize western history as a male sphere. As a result, women were often depicted as being in the shadows, or removed altogether from historical accounts. When mentioned, western ranch and farm women are often portrayed as secondary figures lacking agency and devoted to housekeeping in support of their husbands' labor. ${ }^{1-3}$ More recently, however, women's and gender historians have highlighted women as homesteaders, ranchers, suffragists, and reformers in the American West, allowing for a more full and nuanced representation of the past. As the voices, perspectives, stories, and histories of western farm and ranch women were increasingly heard, researchers realized that a practical fluidity of gender roles existed against the backdrop of a historically male western mystique. ${ }^{4}$

Western women, like most others, were engaged in traditional gender roles and were responsible for domestic tasks such as household management and child-care. They also historically played a large role in organizing their communities' social life (i.e., organizing picnics, fundraisers, bake sales, parent-teacher associations, etc.) while the men were out on the range alone most of the time. Out of necessity, women often took on roles that fell outside the traditional female sphere as well. Ranching, like farming, is a family-based enterprise, and doing work together is a way of life in agricultural communities that contributes to overall success or failure of an operation. In times of crisis, the family's willingness to shift gender roles often saves the operation. Perhaps this is why flexibility in gender roles is more visible in agriculture than in other kinds of work. ${ }^{4}$

In addition to rounding-up cattle and taming wild horses when they rode the range, women also played critical roles in developing new ways to make their operations successful via on- or off-site labor. In an effort to keep their operations 
afloat, many western women worked in town and took advantage of growing demand for professionals and became doctors, lawyers, and businesswomen; something less likely to occur in the eastern United States at the time. ${ }^{4}$

Other women played critical roles in promoting ranch tourism-such as dude ranches-where their duties often crossed gender boundaries. In addition to serving as dude ranch owners, managers, and hosts they also worked as wranglers, trail guides, and packers. ${ }^{4,5}$ This offered guests-particularly eastern elites between the 1920s and 1940s-an opportunity to transgress and modify their own contemporary restraints of gender and class. According to Johnson, ${ }^{5}$

\section{[t] hese ranches reflected and informed larger ideas about the changing roles of men and women...Dudines [women guests] were often enthused about the freedom of blue jeans and baked beans, in contrast to the fancy dresses and finger foods of the east. (p. 438)}

Some scholars believe that because women did much of the farm and ranch work in the past out of necessity, they helped break down social and economic inequalities, and became role models for women across the country. As evidence, they note that western states often led the way in passing laws such as the rights of women to vote, own land, and keep the money they earned. Other researchers, however, highlight a different perspective of women and gender roles in the American West. They argue that women's lives and roles were set back and damaged by the move west. ${ }^{1,3}$

As with most things, there is not one story that accounts for the experiences of all western ranch women. Any consideration of the gendered history of the American West must be tempered by context, circumstance, and personality. While some women were empowered by the diversity of roles and responsibilities afforded them on the frontier, others found their situations confining rather than liberating. Scholars note that many women found themselves overworked and exhausted as they struggled to feed, clothe, educate, and support their children and husbands, while also helping with the difficult tasks of working the land and cattle, baling hay, and harvesting crops. ${ }^{3}$

\section{Women as Community Activists and Leaders Shared Motivations, Qualities, and Approaches}

Regarding environmental issues, women predominate as vocal and passionate activists and leaders in community-based movements related to toxic waste and international development (i.e., ecologically sustainable economic and community development), among others (nuclear power, nuclear weapons, etc.). Research across such cases has documented the following motivations of women activists in these arenas: ${ }^{6-9}$

- Concern for the local, particularly in terms of the health and safety of families and communities;

- Self-articulated ethic of responsibility, care, and interdependence;
- Disillusionment with government and corporate institutions (namely, when their concerns go unanswered and they lose trust in the ability of these organizations to know and do the right thing);

- Marginalization from traditional science and its "legitimated" ways of knowing (when their "lay" attempts to understand issues and draw attention to consequences are disregarded); and

- Focus on equity and democratic processes, and recognition of the link between environmental sustainability, democracy, and peace.

Additionally, their activism is often in response to a strong emotional reaction, and typically develops through happenstance or reliance on intuition and by accident rather than a reliance on training and strategic preparation.

Female community activists and leaders are also often characterized by a degree of humility, with individuals tending to judge themselves as "ordinary" women and often professing gratitude for support received from key individuals or mentors. ${ }^{6-9}$ In at least one study conducted on gender and volunteerism in America, researchers found that the women they interviewed "valued their volunteer efforts more than women in previous studies" (p. 254). ${ }^{10}$ They concluded that contextual factors play a role in shaping women's perceptions of their volunteerism and community service, and should be considered more in future research. ${ }^{10}$

\section{Influence of Gender on Leadership and Problem- Solving Styles}

A review of the literature indicates that women are more likely to be concerned about and active in response to environmental issues at the local level. ${ }^{6,7,11}$ What is the reason for this? Does gender influence their activism in terms of their motivations or reasons for becoming involved in activism, as well as their leadership or problem-solving approaches?

Gender theorists would say yes. Some approach an explanation from a structural or socio-cultural perspective. They note that women lead and participate as activists differently than men because they have long been excluded from traditional power structures and public processes due to institutional, socio-economic, and cultural constraints. Other gender theorists choose to focus more on the individual scale, and examine the essential nature of women as an explanation for gender differences. They note that women are more geared toward caring, cooperation, and peacebuilding; and many theorists highlight maternal abilities of women as shapers of these roles. ${ }^{8,9,12-14}$

According to Meankel-Meadow, ${ }^{15}$ "[g]ender difference research has for decades debated, without successful conclusion, the relative weights of 'nurture' (socialization and education) and 'nature' (biological forces) in forming our understandings of how gender operates both conceptually and behaviorally" (p. 6). At the same time, there are researchers and scholars who refute the notion that gender plays a role in influencing the characteristics and qualities of women activ- 
ists, leaders, and problem solvers. While it is likely that gender differences at both the societal and individual scale have an influence, it is also increasingly known that many other variables may trump, modify, or make more complex the role that gender plays in any particular situation. ${ }^{13,15,16}$

Regarding leadership and problem solving, much has been written about the difference between masculine and feminine styles. Past research on gender differences in both arenas focused on characterizing differences in male and female approaches, and determining which was superior. Female leadership styles were typically characterized as:,13,17

- Cooperative and collaborative, nurturing, empowering, and team-oriented;

- Participatory and reliant on consensus-building processes;

- Favoring relational organizations and networks, and shared responsibility, accountability, and power; and

- Attentive to emotional and experiential data as well as intuitive problem solving.

Similarly, in the negotiation field, women have been traditionally characterized as prone to more problem-solving, relational, contextual, and "caring" methods of dispute resolution. They were also viewed as more concerned about emotional and relational aspects of disputes - and thus - more apt to examine many sides of a problem, more comfortable with the language of psychological needs and problem solving, and potentially more patient. ${ }^{14-16}$

The idea that gender determines leadership style and success remains controversial. Findings regarding differences in the ways women and men lead have produced two streams of evidence: one minimizing gender differences and the other emphasizing them. More recent scholarship suggests that all people possess both feminine and masculine traits; there are many men who can and do demonstrate many of these traditionally feminine characteristics. Further, it is noted that one leadership style is not superior in all instances. Rather, successful leaders (regardless of gender) demonstrate the capacity for both styles and the discernment and ability to employ a particular approach depending on context. ${ }^{13}$

As in the field of leadership, no clear, robust, or conclusive findings exist regarding gender differences in dispute resolution. Current scholarship suggests that while gender may matter, the difference gender makes is quite variable. As such, contextual elements (i.e., experience, age, roles, topic, setting, etc.) may dampen previously perceived gender differences, or at least make them more difficult to dissect out. ${ }^{15,16}$

\section{Women Ranchers as Founding Members of Range-Management Collaborations}

In addition to considering the various theories describing female activists, leaders, and problem solvers in general-and western ranch women in particular-it is equally important to consider the unique perspectives, stories, and histories of individuals. In the remainder of this article, I focus on contemporary individual accounts of four women ranchers who are community-based, collaborative leaders on western rangelands. The following material describes and analyzes experiences of Robin Boies, Wink Crigler, Becky Hyde, and Caryl Elzinga. Specific roles and activities vary greatly across these women and within each organization. They range from conducting potlucks to outreach and information sharing, agenda development and facilitation, data collection, grant writing, catering, preparing congressional briefings, involvement in legal negotiations, etc.

In addition to their work with individual, communitybased, collaborative groups, each of these women or members of their organizations are also members of the Rural Voices for Conservation Coalition (RVCC). Founded by Sustainable Northwest, RVCC is a network of organizations that have banded together with the purpose of linking individual rural leaders to share experiences and best practices, while also giving these leaders a voice in national policy discussions. The RVCC focuses on policy issues that affect rural communities, public lands management, and the continuation of a natural-resource-based economy in the American West. The group is committed to finding and promoting policy solutions through collaborative, place-based work that recognizes the inexorable link between the long-term health of the land and the well-being of rural communities. ${ }^{\text {ii }}$

\section{Robin Boies}

Robin (Fig. 1) and her husband Steve own the Vineyard Ranch near Contact, Nevada. Consisting of almost 90\% public land, the ranch includes sagebrush steppe and riparian areas, providing opportunities for a thoughtful, holistic management approach. In 1995, a neighboring ranch initiated the Shoesole Group as a way to support collaboration among ranchers and federal, state, and local organizations. The Boies family has participated in this group from the beginning. The Shoesole Group has done much to foster better communication and relationships among these parties on many issues, as well as to collaboratively develop on-the-ground management strategies.iii

The group uses a collaborative, consensus-based process to address natural resource management focused on sustaining healthy and productive public and private landscapes. Their stated goals are:

- Building and maintaining positive and meaningful relationships that include friendship, respect, trust, equality, and openness to ideas while maintaining independence;

- Commitment to economic stability, continuity, and security of family ranching, with the flexibility to change and time to dream or stretch for new goals; and

"For more information on the RVCC, see http://www.sustainablenorthwest. org/what-we-do/programs/rural-voices-for-conservation-coalition

iiiFor more information on the Shoesole Group, see http://www.theshoesole.org 


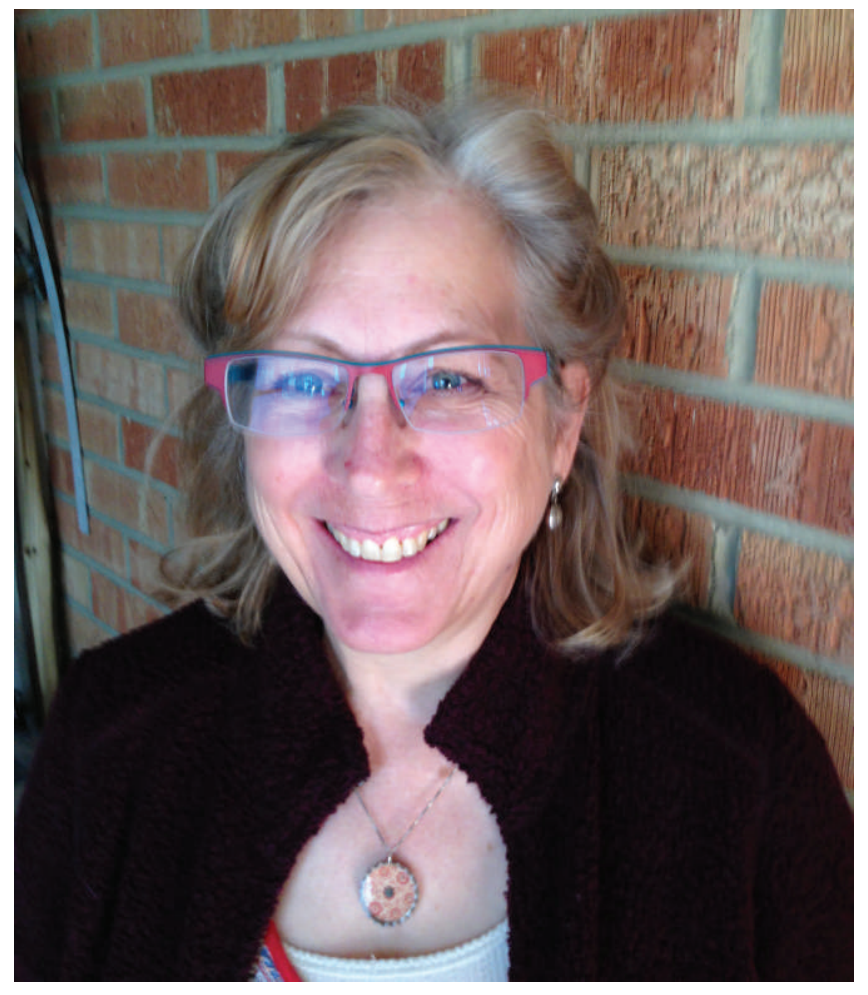

Figure 1. Robin Boies. Photo courtesy of Boies family.

- Enhancing clean air, water, open space, recreational opportunities, cultural resources, wildlife, and landscape health and productivity.

Members firmly believe that achieving these goals will provide the potential for health, passion, compassion, contentment, happiness, love, and peaceful conflict resolution.

Drawing on the skills and lessons learned from the Shoesole Group, the Boies family and other landowners have recently united to form the Stewardship Alliance of Northeast Elko (SANE). SANE is a landowner-driven alliance focused on rangeland issues in northeastern Elko County (over 1.7 million acres of private/public lands), with a particular interest in finding innovative, cooperative, and landscape-scale solutions to sage grouse conservation. The alliance is grounded in common values and recognition of the interrelationship between good habitat and economic viability, the need to work together to provide a rich heritage through education, and efforts to balance science with local knowledge and collaboration. The group has no formal hierarchy, and the decision-making process is participatory and consensus-based.

\section{Wink Crigler}

Wink (Fig. 2) owns the X-Diamond Ranch, originally purchased by her family in 1890 . In response to the changing context of rangeland management in the American West, particularly in terms of competing uses and increasing conflict about public land grazing, Wink and a dedicated group of ranchers formed the Ranching Heritage Alliance (RHA) in 2008. The

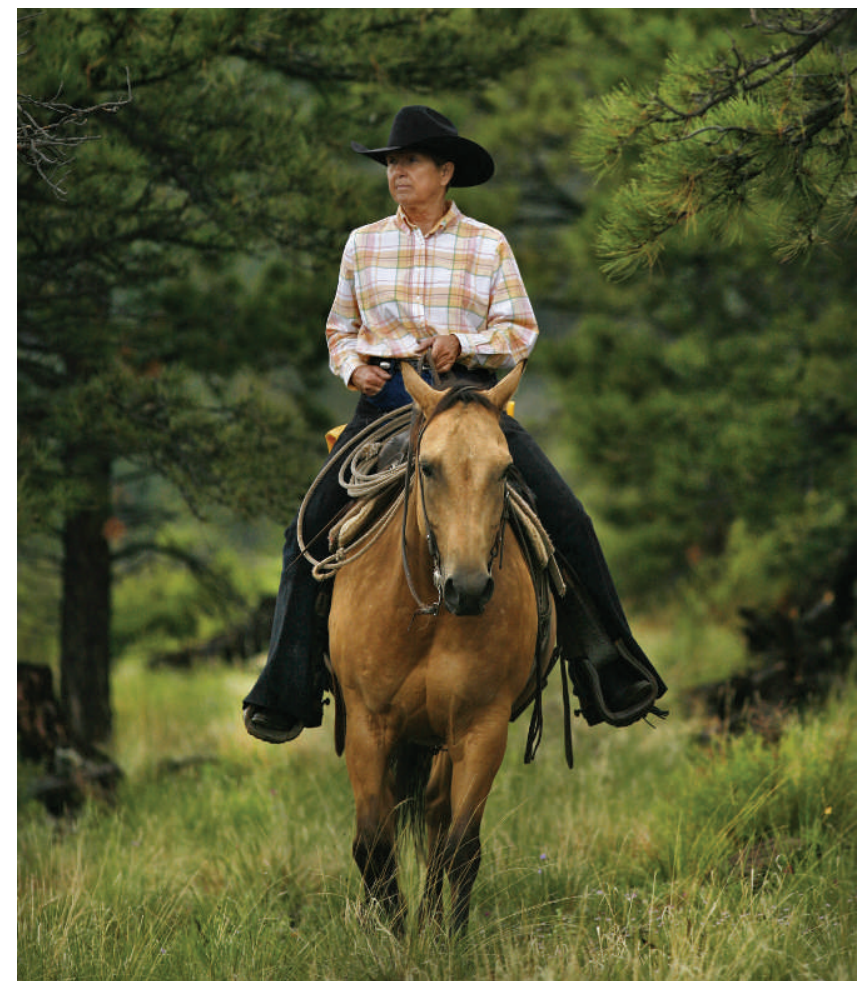

Figure 2. Wink Crigler. Photo courtesy of Scott Baxter Photography.

RHA is a loose-knit, but concerned group where anyone who has an interest in learning about the values of land and resource use and management can connect with, and become a meaningful part of, a collaborative and educational process. ${ }^{\text {iv }}$

The group's mission is to turn conflict into collaboration for improved stewardship and productivity of public rangelands, and across the landscape, by changing the tone of community relations. The group seeks to create dialog among interested parties, with the goal of developing science-based solutions for healthy rangelands. They are working to break down the barriers between landowners, grazing permit holders, and the various federal agencies in an effort to sustain food production, family values, community stability, and natural resource viability-including protection of open space. In other words, to become caretakers of the land and leave things better for the next generation. The group has no formal hierarchy and membership is open to all, with the only requirement being that everyone participates, asks questions, shares concerns, suggests educational opportunities, attends other educational functions, invites others, and incorporates new knowledge and skills into their operating plans.

\section{Becky Hyde}

In 2001, a severe drought in the upper Klamath Basin triggered clashes over limited water supplies. Fish protections

iv For more on the RHA, see http://www.snr.arizona.edu/project/ collaboration 


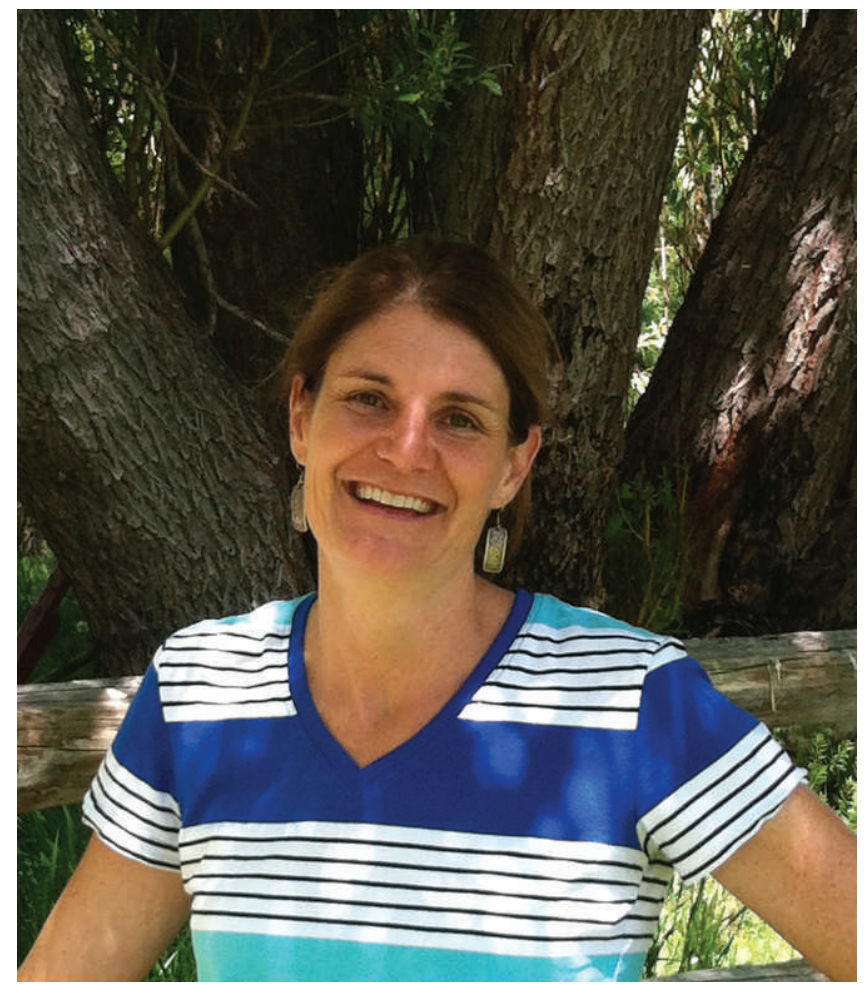

Figure 3. Becky Hyde. Photo courtesy of Laura Van Riper.

mandated by the Endangered Species Act (ESA) were the basis of a decision to cut off water for irrigators, and the tension-filled situation became a national symbol of western water wars and environmental conflict. A second year of drought followed in 2002, but this time federal agencies channeled water to irrigators, contributing to one of the largest fish die-offs in history. Exhausted from legal challenges that resulted in little to no progress toward a solution, a few courageous individuals resorted to a new tactic, namely working together. Becky (Fig. 3) and her husband Taylor were two of those individuals.

In an effort to put a practical face on a new type of conservation, the Hydes worked with various partners to purchase the Yainix Ranch near Beatty, OR in 2002. By purchasing one of the most degraded properties in the area-one they felt embodied all of the reasons why the fish, the greater landscape of the basin, and their community were imperiled-they intended to demonstrate how cooperation could return the ranch to productivity, the basin to proper ecological function, and the community to economic prosperity. The Yainix Ranch was the Hyde's experiment to test a simple hypothesis: could sustainable cattle ranching and systemic land restoration be combined and successfully pursued in the context of a broadly conceived partnership - and could the lessons learned transform the Klamath Basin?v

"For more information on the Yainix Ranch, see http://www. cooperativeconservation.org/story.shtm
Becky passionately believed that if they could fix the ranch, the Klamath Basin itself and all of its residents could benefit from the lesson. Indeed, the restoration practices, lessons learned, and relationships built from the Yainix partnership have carried forward into water-settlement negotiations for the Klamath Basin where a group representing more than 25 organizations worked to craft the Klamath Basin Restoration Agreement (KBRA). Sometimes referred to as the "settlement agreement," the KBRA proposes collaborative solutions to water adjudication issues and takes a holistic approach to ecosystem restoration that benefits wildlife, the environment, local residents, cultures, and economies of the region. ${ }^{\mathrm{vi}}$

\section{Caryl Elzinga}

Caryl (Fig. 4) and her husband Glenn own Alderspring Ranch near May, Idaho - the purchase of which was a collaborative effort in its own right. The Elzingas are also founding members of the Central Idaho Rangelands Network (CIRN), a group of ranchers and conservationists selected and supported by the Nature Conservancy to come together to develop and implement innovative approaches to land and water management that sustain and enhance the natural and community values of their area-over 1.5 million acres of public and private lands. The overarching purpose of the network is to sustain the natural and social values of the region by improving the economic and operational stability of ranching operations and achieving increased wildlife abundance and habitat condition through the conservation and restoration of land. vii

The group is committed to working in tangible, on-theground, and cooperative ways to forge new approaches to

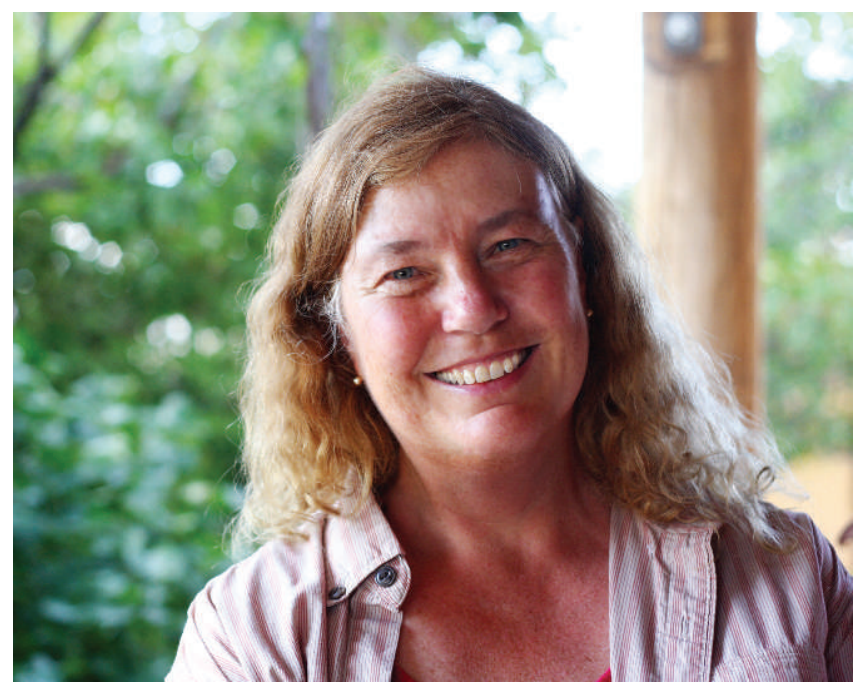

Figure 4. Caryl Elzinga. Photo courtesy of Elzinga Family.

viFor more on the KBRA, see http://www.kwua.org/klamath-settlementagreements.html

viiFor more information on the CIRN, see http://idahorangelands.org/ 
achieving improved land, economic, and community health. Specifically, CIRN goals are focused on:

- Building the value and productivity of their ranches so that they will support their families over multiple generations;

- Protecting and enhancing the incredible natural and scenic values of their region, including species such as salmon, pronghorn, and sage grouse, with which they share the land and the natural communities and processes that sustain them;

- Embracing the diversity and size of the landscape and recognizing the need to cross property boundaries and traditional roles to work at a meaningful scale;

- Fostering a spirit of collaboration and learning that leads to positive things happening on the ground; and

- Working in a practical, constructive, and open manner.

\section{Summary of Panelists' Motivations, Characteristics, and Qualities}

In this section, I focus on common themes among across the stories shared by the four women. In describing their individual motivations for becoming community activists, the four women ranchers echoed other women activists involved in community-based movements focused on environmental and other issues. They also share similar characteristics and qualities among themselves and with other similarly positioned women regarding their approach to leadership and problem solving or dispute resolution.

\section{Concern for Community Well-being}

All of the collaborative groups mentioned above speak of the interconnections among sustainable ranching, healthy communities, and well-functioning ecosystems, and explicitly work to maintain these important linkages. In describing their individual concern for the future of their communities, Robin and Wink talk about the future of ranching in the American West and how ranchers are going to survive in the face of increasing conflict, particularly with regards to public land grazing. They reflect on their belief in the connection between healthy economies, communities, families, and ecosystems, and view of ranching and other traditional uses of the land as central pieces of the whole.

Caryl echoes this sentiment, but takes a slightly different turn in describing her concern for how young people with a passion for sustainable agriculture can make a life and living on a ranch without access to inherited equity in cattle, land, or equipment. In further describing the connection between public and private lands, Robin and Caryl note that most of the private landowners who control water in Nevada and Idaho are dependent on federal permits (as is the case in most of the American West). Wink also notes the critical tie between private and public rangelands and reminds us, "if you're eating, you're part of agriculture."

Coming from a slightly different angle, Becky describes the impacts of events in the Klamath Basin in the early 2000s in terms of community health and safety. In her words, they "ripped our community to pieces." As evidence, she recounts the story of a young Indian boy in the community of Chiloquin whose head was kicked in at a party in 2001 by a white boy in response to an argument over water, and later died. She also highlights that Hispanic families with multi-generational ties to the community had to leave because of lack of work on the farms, and notes that health clinics in the small town of Merrill reported drastic increases in depression, and the crisis center was being used to capacity. Finally, she mentions the children who were slated to come back to the farm but chose not to. In the end, she believes that, "the story of the Klamath Basin is a long one that has people treating each other and the land in certain ways, at certain times, and sometimes good coming from that. I still believe that when we have the peace of mind to work together through tough problems, our communities will get healthier."

\section{Ethic of Care, Responsibility, and Interdependence}

Robin describes her relationship with the land as more of "covenant with," rather than "dominion over." She feels that land management is not separate from the larger questions of life regarding how we treat people, animals, and the land. To her, "it's about living a life of reciprocity, the Golden Rule" and she believes that emerging systems of land management must be based on mutuality rather than dominion over.

Wink (like others) describes her ranch in holistic terms, touching on current and past families, wildlife, plants, water, and riparian resources as well as its history as a working cattle ranch. Referencing an ethic of care, responsibility, and interdependence, Wink recites a portion of the Cowboy Prayer: "O Lord, may no man, woman or child go hungry." For her, "this is really the bottom line of what it's all about-maintaining those resources in a productive manner so that we have the answer to that old cowboy's prayer."

Becky describes meetings between farmers, ranchers, and the Klamath Tribes that occurred over several months in 2005. She talks about how the farmers in the room were grappling with the fact that the Tribes had lost their fishery and how getting to this point required a major shift in their thinking. She describes a point in time where the farmers asked the Tribes how they could compensate them financially for the loss of the fish. However, the Tribal members explained that the complex cultural relationship they have with the fish does not lend itself to monetary valuation. After watching the participants wrestle with this issue for a while, Becky (with baby in tow) asked what it would mean if someone just said "sorry." Chairman Foreman, with tears in his eyes, said "a million dollars." This simple exchange highlights an ethic of care and responsibility and had a profound impact in terms of shifting the social dynamics and relationships between key players in the ongoing Klamath issue.

\section{Disillusionment With Government Institutions}

Robin, Wink, and Caryl describe their disillusionment with government institutions in relation to the ongoing conflict 
over federal lands grazing. Robin notes that societal values have changed and - as a result-are voiding the social contracts that ranchers and homesteaders made with the federal government. She also laments the difficulty of fitting collaborative processes into the federal bureaucracy. Wink explains that one of the major issues is the unrealistic management expectations placed on permittees due to calls for science-based management-when in reality federal management agencies often do not have the on-site monitoring data needed to make decisions.

Expressing a similar concern, Caryl mentions that CIRN members are adamant about the need to monitor. In part, this rose from a concern that federal agencies would not be able to meet their monitoring commitments, and that such a failure would leave permittees vulnerable to legal challenges. On a deeper level, CIRN members-who are demonstrated conservationists and problem solvers - are frustrated with the lack of agency attention to, and support for, their ideas and evidence of on-the-ground improvements. In Caryl's words, "they see things that they would like to change, but feel that without data they cannot get the attention of agency resource specialists. They also see things they believe are improvements, but feel their stories of improvement are inadequate and ignored." Further, Caryl notes that the efforts of CIRN members to address these issues have suffered from a lack of interest and involvement on the part of the agencies.

\section{Marginalization from Traditional Science}

The four women approach the issue of traditional science and its legitimated ways of knowing from different angles. On one hand, these women recognize the need to increase the capacity of lay people to more effectively participate in traditional science. At the same time, they push for acceptance of alternative ways of knowing and the incorporation of more perspectives into the development of information in support of decisions.

In discussing the role of science, Robin notes the need to balance science with local knowledge as part of a collaborative decision-making process. In her opinion, science needs to lead us, but we must also recognize that land management does not always 'fit the rule.' "The elements of resiliency, unpredictability, and artistry seem to be forgotten. As humans, we seem to want answers that settle the dust and resolve away every question, sometimes at the expense of truth."

Given the growing importance of monitoring data in federal rangeland management, Wink and the RHA are primarily focused on improving research and public education in an effort to prepare their members (many of whom are federal grazing permittees) to "know more about their place than anyone else." This includes having detailed monitoring projects and using data-collection methods that record trends and provide documentation needed to prove (and defend) management effectiveness.

Echoing this sentiment, Caryl explains that because many ranchers within CIRN feel their stories are ignored, they are trying to adopt the language of agency biologists. In their first year as a group, CIRN members built an "atlas of information" for each ranch operation that includes maps of wildlife habitat, water resources, and range improvements, as well as monitoring data and contrasts with historical and contemporary photos. The group also sponsored workshops on agency planning processes so members can better understand, navigate, and effectively engage in such efforts.

In addition to identifying ways for lay people to engage in traditional science, Caryl also advocates for the importance of gathering rancher's stories - and the knowledge that lives in them-and communicating and incorporating this information into land management. Caryl hopes that over time, CIRN can accomplish this in her community. Caryl notes that there is a substantial body of literature regarding local and traditional ecological knowledge. She describes one study that showed western ranchers possessed substantial ecological understanding, and that this knowledge was communicated primarily through stories. ${ }^{18}$

Emboldened by this, Caryl describes how recent monitoring projects undertaken by CIRN began with a series of interviews designed to get members to articulate what they knew and what kind of additional information would be most useful to them in managing their operations. Caryl notes that one of the findings of this exercise was that she had a hard time connecting qualitative stories and ideas to standardized information-collection and monitoring techniques. This bolstered her belief in the need for different approaches to information collection and the generation of knowledge.

\section{Focus on Equity, Democracy, and Peace}

Both Robin and Caryl focus on the effects of specific processes within their groups. Caryl recounts how the messy and time-consuming process of CIRN members muddling through and figuring out who they were as a group, and what they wanted to do, actually helped members develop characteristics associated with successful groups. Specifically, she mentions the following outcomes: "trust and understanding of our different perspectives, a recognition and appreciation for the different gifts that we bring to the group, and a genuine like for each other."

Robin talks in general about the importance of having processes that invest in relationships, trust, and respectful listening. She specifically mentions the importance of the meeting circle where words are heard and respected, and different perspectives are valued by all members. She believes, "collaborative processes can be an equalizer; grassroots democracy at work, where decision are made based on a diversity of voices."

In describing the role of the Yainix Ranch partnership in fostering a more democratic approach to conflicts over rivers, fish, and cows, Becky notes that they welcomed a lot of different individuals with different perspectives onto the ranch and essentially became a catalyst for people in the community coming together around resource issues in a "safe zone." The development of a shared understanding of the issues and relationships among players carried forward into the more re- 
cent formulation of the settlement agreement. According to Becky, "Over the past five years, so many people have come together across historic divides and forged agreements in an attempt to solve problems. These are regular people working together, in honest ways, to try and stabilize our community."

Robin also highlights the importance of directing attention to intergenerational equity and describes her personal and ongoing struggle to keep ranch children engaged and hopeful. She notes that the focus of the Shoesole group is "generative, it is about coming generations and deep time." Similarly, Wink echoes the importance of "leaving the landscape better for the next generation and others who have not had the opportunity to know the richness of life on a sustainable and productive ranch." She believes it is her job to ensure they are sustained. Caryl also speaks to intergenerational issues in describing the importance of capturing, preserving, and learning from the stories of long-time ranchers before they pass away and a wealth of ecological knowledge and understanding disappears.

Finally, Robin speaks to the link between sustainability, democracy, and peace. She describes how the terrorist attacks of September 11, 2001, and the associated wars, made her realize that she had to work for peace, which started at home. She talked about the fact that wars are waged over natural resources, and the victims of war tend to be women, children, and the elderly. She describes her personal commitment to no longer contribute to any system that systematically vilifies another group of people, as is typical in the conflicts over western rangelands, noting that history is riddled with examples of this tactic and its devastating outcomes. Rather, she believes that long-term social change comes from peaceful resistance to the status quo.

\section{Development through Happenstance}

For Robin, the rise of community-based, collaborative groups across the western United States is an inspiring and positive, albeit unplanned, outgrowth of the rangeland conflicts. In her words, these groups are "the good news, the unintended consequences that grew out of conflict." She explains that while she originally entered into collaborative endeavors with a self-preservation motive, she now believes that she is part of a movement that is bigger than rangeland management and ranching. In her words, "it is a form of civil disobedience, a counterculture movement more intent on finding solutions than in perpetuating the fight over land management in the western United States."

Wink explains that she "didn't know the word 'collaboration' until about 10 years ago, when I found myself involved in it." Upon further reflection, however, she realized that her family has a long history of leadership and engagement in community-based, collaborative efforts, noting that her grandparents were founding members of the Arizona Sportsmen Association in the late 1800s (later known as the Arizona Game and Fish Department) and her mother founded the local parent-teacher association.
Similarly, Becky describes her feeling of having a responsibility to work across divides as coming from her childhood, and her experience growing up on a ranch and watching her parents working with others and making uncommon allies. She notes their founding roles in both the Trout Creek Mountain Working Group, one of the first collaborative groups formed to address issues regarding ranching, rivers, and endangered fish on federal and private lands, and Country Natural Beef, a consensus-based ranching cooperative that was established in 1984 with a focus on maintaining "Healthy Animals, Healthy Environment, and Healthy Families."viii

In describing her own initial forays into working across divides, Becky recounts her role in negotiating the first waterrights settlement in the Klamath Basin between her motherin-law's ranch (one of the oldest ranches in the area) and the Klamath Tribes. She describes this endeavor as being a long, arduous, and emotional process in which the parties worked through their rocky past and long-standing hurt feelings. She recounts that there was "not a dry eye in the room on the day that the settlement was signed at her mother in-law's dining room table with all of the Tribal Council members present." She further explains that what was settled that day was much deeper than water rights. New loyalties, alliances, and friendships were made and joined by a commitment to work together to settle these issues at a larger scale by creating opportunities for people to come together and listen to each other, while also being willing to change and innovate. These continuing efforts have manifested in the Yainix Ranch partnership and the KBRA.

\section{Reflections on Gender}

While the similarities that the four women highlighted in this article share with other female, community-based, environmental activists cannot be ignored, the determination of the degree to which gender has influenced the motivations, characteristics, and approaches of these women, and at what scale (individual and/or societal), remains a topic worthy of future study. As previously noted, the accounts provided by the women themselves generally discount the importance of their gender, and they label their efforts as "business as usual" or "nothing special." This raises some interesting questions, namely:

- Are these accounts the result of the fact that gendering can be extremely unconscious? Are these panelists simply unable to recognize the inordinate roles they have played as women leaders in rangeland collaborations?

- Are they reflective of context? Is the achievement of some level of gender-equity within the western United States dampening the influence of gender?

- Do these examples provide evidence that gender is a muted influence on the motivations, characteristics, and ap-

viiihttp://www.countrynaturalbeef.com/ 
proaches of these particular women as community activists, leaders and problem-solvers on western rangelands?

The answer is likely a combination of the three.

In considering the accounts of the four women ranchers, it also quickly becomes apparent that these women are indeed humble and do not seek recognition for their specific contributions to these efforts. Reflecting Garland's findings,

"[t]he tales of these women are far more dramatic than the tellers apparently believe them to be... they see their political lives and commitments as simple, and in many cases as natural to them as breathing" (p. xv). ${ }^{6}$

They are also passionate, driven, tireless, and spirited western women, who are motivated by things bigger than themselves and focused on "getting the job done." In their roles as practitioners, they don't spend much time systematically analyzing the behavioral and cultural aspects of gender and, thus, are probably less attune to its influence. That said, most of the women mentioned gender, albeit minimally, in their SRM presentations.

Wink began her presentation noting that she hadn't thought about gender and its influence until asked to participate in the panel discussion that forms the basis for this paper. She explained that growing up on a western ranch as one of three girls, "if there was work to do, you just did it. It didn't matter if you were a woman; you didn't think about roles, just your job."

In contrast, Robin referred to continuing challenges within the ranching culture, noting, "I've never seen anyone take notice or mention any concern over the lack of diversity in the pretty much all white-male ranching industry in Nevada. There is no affirmative action committee." She also described the perpetuation of collectively harbored, ingrained beliefs about things like whether daughters can inherit the ranch. In recounting the collaborative experience, she believes that the freedom and act of speaking openly and honestly in meetings is more unique for some of the men than it is for her as a woman.

In describing her gendered experience, Becky explains that she had an unusual childhood, "growing up in a progressive, open-minded wing of the livestock industry with a mother who challenged the boundaries of what it meant to be a woman in a primarily conservative, rural community." She also had a father who liked to learn new ideas and wasn't threatened by them. "He loved spirited women, and supported and encouraged our efforts to engage." Today, her activism is also supported and encouraged by her husband, as well as other men who embrace feminine leadership styles and qualities. She provides this background because she realizes that "it is not always easy for women to rise up in rural places."

When considering the influence of gender on the four women ranchers, their accounts echo the findings of other contemporary researchers and scholars; it is not so much that gender doesn't matter, but that the degree to which it mat- ters and its impact on outcomes may not be as great as once thought. Rather, it is tempered by context, circumstance, and personality, and experienced differently by each woman. For a variety of reasons, these four women are less constrained and confined by gender roles, and, so, pay less attention to them. While each of the panelists acknowledged the importance (for example) of traditionally feminine characteristics like listening, relationship building, and compassion, they do not specifically tie these traits to gender. This tendency to highlight commonality over difference may contribute to their success as bridge-builders, networkers, organizers, leaders, and peacemakers within their communities.

\section{The Way Forward: Building Upon Individual Success}

As community-based, collaborative management continues to gain a foothold on US rangelands, it is worth considering the role that women play in this nascent, but growing, social movement. The four women ranchers highlighted in this article are examples of female activists, leaders, and problem solverssharing many similarities with other, similarly positioned women. If we agree that a community-based, collaborative approach to addressing rangeland conflicts is beneficial, then how do we "scale-up" this process? And, specifically, how do we identify future leaders and empower them to take on similar roles?

First, it is important to resist stereotypes (positive or negative) that reinforce the notion that all women share the same qualities and instead focus on identifying women and men who are well suited for the task or share common personalities, perspectives, traits, and strengths with individuals in similar roles. For a number of reasons, including the fact that success as a leader is largely dependent upon aptitude and commitment, it is best if individuals self-select as leaders. While the initial shift in thinking about themselves and their roles that occurs during the self-identification process is critical to success, long-term success ultimately lies in finding the resources to effectively organize their communities and challenge existing systems (i.e., political, scientific, and bureaucratic). The next step in scaling-up is finding ways to support these individuals as they move forward. ${ }^{8,9}$

While many women find or develop a number of resources within themselves as they struggle and succeed in learning about community organizing, politics, science, and influencing public opinion, they also learn to cultivate external resources by gaining mentors in science, political, or bureaucratic processes, and community-based problem solving. ${ }^{8}$ In considering the situations of the four women ranchers, it seems that the type of support needed has less to do with being a woman (although some discussed the importance of having support as a woman in these roles), and more to do with helping them develop the skills and confidence needed to effectively navigate the complex technical and social situations they face. Most of the panelists mentioned the critical role that individual mentors and support organizations focused on serving this need have played in their success (i.e., 
The National Riparian Service Team, university extension, Sustainable Northwest, The Nature Conservancy, etc.).

Additionally, it is also important to scale-up local efforts in terms of embedding them within a larger socio-political context and creating communities of interest or practice for women leaders to connect with and grow from. Although it is important to understand the particular situations that exist on the ground, community-based or grassroots efforts do not exist in a vacuum. Rather, they often rely on the support of extended networks and are inexorably linked to socioeconomic, political, and bureaucratic systems that operate at regional, national, and even global scales. Groups, such as RVCC, not only provide forums for inserting the perspectives and concerns of community-based efforts into the development of national policies, but also provide local leaders with access to the learning and networking opportunities afforded by a community of practice. ${ }^{19}$

\section{Acknowledgments}

The author thanks Robin Boies, Wink Crigler, Becky Hyde, and Caryl Elzinga for their inspiring stories and willingness to take time and energy out of their busy schedules to help make the panel, and this paper, a success. Comments from Rangelands co-editors and two anonymous reviewers helped improve this paper. The following donors provided financial support for the four panelists to attend the "Women as Change Agents on the World's Rangelands" symposium at Oklahoma City: 1) the SRM Oklahoma Organizing Committee; 2) the Society for Range Management Pacific Northwest, Arizona, and Nevada Sections; 3) the National Riparian Service Team; 4) the Brainerd Foundation; and 5) Sustainable Northwest. They are warmly appreciated for this support. Their panel presentations provided significant input for this article.

\section{References}

1. Andre-Beatty, P. 2000. Disrupted conventions: gender roles in Mildred Walker's 'The Curlew's Cry' and 'Winter Wheat' [MS Thesis]. Missoula, MT, USA: University of Montana. 97 p.

2. JAсовs, M. 2011. Western history: what's gender got to do with it? The Western Historical Quarterly 42:297-304.

3. Riley, G. 1989. Women's responses to great plains living. Great Plains Quarterly 9:174-184.

4. Schackel, S. 2011. Working the land: the stories of ranch and farm women in the modern west. Lawrence, KS, USA: University Press of Kansas. 158 p.

5. Johnson, A. R. 2012. Romancing the dude ranch, 1926-1947. The Western Historical Quarterly 43:437-461.

6. Garland, A. W. 1988. Women activists: challenging the abuse of power. New York, NY, USA: The Feminist Press at The City University of New York. 146 p.
7. Rodda, A. 1993. Women and the environment. Atlantic Highlands, NJ, USA: Zed Books Ltd. 180 p.

8. Brown, P. and F. I. T. Ferguson. 1997. "Making a big stink": women's work, women's relationships, and toxic waste activism. In: Carolyn E. Sachs [ED.]. Women working in the environment. Washington, DC, USA: Taylor and Francis. 317 p.

9. Hassan, Z. and A. D. Silong. 2008. Women leadership and community development. European Journal of Scientific Research 23:361-372.

10. Petrezelka, P. and S. E. Mannon. 2006. Keepin' this little town going: gender and volunteerism in rural America. Gender and Society 20:236-258.

11. SAchs, C. E. 1997. Introduction: connecting women and the environment. In: Carolyn E. Sachs [ED.]. Women working in the environment. Washington, DC, USA: Taylor and Francis. $317 \mathrm{p}$.

12. Nelson, A. 2012. Vital voices: the power of women leading change around the world. San Francisco, CA, USA: JosseyBass. 272 p.

13. Klenke, K. 1996. Women and leadership: a contextual perspective. New York, NY, USA: Springer Publishing Company, Inc. 307 p.

14. Birkoff, J. Gender, conflict and conflict resolution. Available at: http://www.mediate.com//articles/birkhoff.cfm. Accessed 3 April 2012.

15. Menkel-Meadow, C. 2012. Women in dispute resolution: parties, lawyers and dispute resolvers-what difference does gender make? Dispute Resolution Magazine (Women in ADR) 18:4-8.

16. Weaver, D. and S. W. Coleman. 2012. The literature on women and negotiation: a recap. Dispute Resolution Magazine (Women in ADR) 18:13-16.

17. Lowe, M. 2011. Breaking the stained glass ceiling: women's collaborative leadership style as a model for theological education. Journal of Research on Christian Education 20:309-329.

18. Knapp, C. N. and M. E. Fernandez-Gimenez. 2009. Knowledge in practice: documenting rancher local knowledge in northwest Colorado. Rangeland Ecology \& Management 62:500-509.

19. Wegner, E. C. And W. M. Snyder. 2000. Communities of practice: the organizational frontier. Harvard Business Review 78:139-145.

Author is Social Scientist, National Riparian Service Team, Bureau of Land Management, Prineville, OR 97754, USA, lvanripe@ blm.gov.

Rangelands 35(6): 47-57

doi: 10.2111/RANGELANDS-D-13-00041.1

(C) 2013 The Society for Range Management 